\title{
Utilization of Bio Slurry with Input of Buffalo Faeces and Water Hyacinth (Eichornia crassipes) With Various Doses of MOD (Microorganism Decomposer) on Productivity of Indigofera zollingeriana.
}

\author{
Saudarman Sitanggang, Nurzainah Ginting, Yusuf Leonard Henuk, Yunilas, \\ Hamdan \\ Animal Production Program Study, Faculty of Agriculture, University of North Sumatera, \\ Medan 20155, Indonesia \\ E-mail: saudarmansitanggang@gmail.com
}

\begin{abstract}
SAUDARMAN SITANGGANG, 2018: Utilization of Bio Slurry with Input of Buffalo Faeces and Water Hyacinth (Eichornia crassipes) With Various Doses of MOD (Microorganism Decomposer) on Productivity of Indigofera zollingeriana. Guided by NURZAINAH GINTING and YUSUF LEONARD HENUK.

The aim of this research was to inventigate the effect of bio gas slurry with the input of buffalo feces and water hyacinth (Eichornia crassipes) with various doses of MOD (Microorganism Decomposer) on Indigofera zollingeriana productivity. This research was conducted in Parbaba Village, Pangururan District, Samosir Regency of North Sumatera from April to November 2017. The design used in this research was split plot design with 4 replications. Factor I dose of $M O D, M 1=1$ liter $/ 150$ liters and $M 2=2$ liters $/ 150$ liters. Factor II dose of bio-slurry fertilizer with input of buffalo feces and water hyacinth parameters, $P 0=0$ (as control), $P 1=20, P 2=40$. Were plant height, stems diameter, fresh weight production, and dry weight troduction.

The results showed that dosage of MOD gave significant effect on plant height, stem diameter, fresh weight production, and dry matter of Indigofera zollingeriana. The provision of bio gas slurry with buffalo faeces and water hyacinth with various doses of $M O D$ has a significant effect on plant height, stem diameter, fresh weight production, and dry matter. The conclusion of this research that increasing the dose of MOD and fertilization dose of Indigofera zollingeriana gave a better result.
\end{abstract}

Keywords: slurry, buffalo faeces, water Hyacinth, productivity, indigofera zollingeriana

\section{Introduction}

Forage forage plays an important role in the development of livestock business. The procurement of forage forage needs to be well managed. The objective of forage management is the availability of forage in sufficient quantities, good quality and continuous throughout the year Reksohadiprodjo [1].

The slurry of bio gas which is a by-product of bio gas technology can be utilized as a source of soil organic matter like manure. Sluri is useful for the fertilization of vegetable crops, fruits and trees / perennials. The slurry of bio gas has an advantage when compared to manure or compost that is slurry has nutrients that can be exploited by the plant Ginting and Mustamu [2].

According to Lazcano et al., [3] livestock manure is a valuable natural resource that can be used as a fertilizer, because it contains macro and micro nutrients needed for plant growth. The material from the remaining process of bio gas in the form of a thick liquid (sluri) can be used as organic fertilizer.

Water hyacinth (Eichhornia crassipes) is a weed plant in aquatic area that lives floating on deep water 
or develops rooting in mud in shallow water. Hyacinth multiply very quickly, both vegetatively and generatively. Proliferation by vegetative means doubled twice within 7-10 days.

The addition of bio-activator MOD-71 for composting is used to enrich the feces of buffalo and water hyacinth because in the bioactivator contains many bacteria and fungi such as Azotobacter, Bacillus, Nitrosomonas, Nitrobacter, Pseudomonas, Cylophaga, Sporocytophaga.

Forage leguminosa indigofera zollingeriana requires organic fertilizers as other plants. This forage is a woody legume crop and has a long productive lifespan.

\section{Materials and Research Methods}

The research was conducted in Parbaba Village, Pangururan Subdistrict, Samosir Regency, Sumatera Urata. The study lasted for 7 months with 2 weeks land preparation and was conducted from April to November 2017. The materials used were legume seeds of 2-month-old indigofera zollingeriana, slurries of buffalo feces and water hyacinth, water, MOD. The tool used is hoe, gembor, meter gauge, machetes, oven, electric scales, data books, calculator, slider, measuring tape, plastic strap, envelope, biodigester 150 liters of 2 pieces. The experimental design used is a split plot design using two factors, namely:

I. The first factor used as the main plot is the MOD dose

$\mathrm{M}_{1}=$ Fertilizer slurry buffalo and water hyacinth feces with 1 liter / 150 liter MOD

$\mathrm{M}_{2}=$ Fertilizer slurry buffalo and water hyacinth feces with MOD 2 liter / 150 liter

II. As sub plot (sub plot) is a different dose of fertilization each treatment, among others:

$\mathrm{P}_{0}=$ Without the use of bio-slurry fertilizer

$\mathrm{P}_{1}=$ Given a slurry gas fertilizer with a dose of $166 \mathrm{~g} / \mathrm{plot}$ (20 ton / ha / year)

$\mathrm{P}_{2}=$ Given a slurry gas fertilizer with a dose of $333 \mathrm{~g} / \mathrm{plot}$ (40 ton / ha / year)

The data obtained will be analyzed, and if the treatment is significantly different $(F \geq 0.5)$ or very real $(F$ $\geq 0.1)$ then further tested by using Duncan test. The research parameters were plant height, stem diameter, fresh weight production, and dry weight production

\subsection{Plant height}

Plants were measured till before harvesting to obtain high plant values from each treatment. Plant height is measured from the soil surface to the highest part of the indigofera zollingeriana plant.

\subsection{Stem diameter}

Measurement of stem diameter was $10 \mathrm{~cm}$ above the ground by clamping the stem of the plant with a sliding range. Furthermore, the measuring lever shifted until it did not move anymore and visible numbers on the slide.

\subsection{Fresh Weight Production}

Fresh weight is obtained from the weighing of each treatment in fresh form. The production of fresh ingredients is calculated at the time of defoliation. Leaves and twigs are tied neatly with plastic straps, then weighed.

\subsection{Dry Material Production}

Dry matter is obtained from the production of fresh weight of legume after weighing, then dioven at $60^{\circ} \mathrm{C}$ for 24 hours, then weighed the weight of the grass.

Furthermore, samples taken as much as 2 grams to know the weight of plants in $105^{\circ} \mathrm{C}$ oven. Conversion is performed between the weight percentage at $60^{\circ} \mathrm{C}$ and at $105^{\circ} \mathrm{C}$ for the production of dry matter. To calculate the production of dry matter plants can be known by the formula:

Production of dry matter $=$ BK Content $\mathrm{x}$ Fresh Production

\section{Results and Discussion}

Table 1. Results of analysis of slurries with buffalo faeces and water hyacinth input with various doses of MOD.

\begin{tabular}{clcccc}
\hline No & Parameter & Unit & \multicolumn{2}{c}{ MOD (liter/150 liters) } & $\begin{array}{c}\text { SNI } \\
\text { organic fertilizer }\end{array}$ \\
\cline { 4 - 5 } & & & 1 & 2 & \\
\hline 1 & C-organic & $\%$ & 3,82 & 4,02 & $>12$ \\
2 & $\mathrm{~N}$ total & $\%$ & 0,19 & 0,26 & - \\
3 & $\mathrm{C} / \mathrm{N}$ & - & 20,10 & 15,48 & $>12-25$ \\
4 & $\mathrm{P}_{2} \mathrm{O}_{5}$ & $\%$ & 0,31 & 0,37 & $<5$ \\
5 & $\mathrm{~K}_{2} \mathrm{O}$ & $\%$ & 0,69 & 0,47 & $<5$ \\
\hline
\end{tabular}




\begin{tabular}{|c|c|c|c|c|}
\hline \multirow{2}{*}{$\begin{array}{l}\text { Dose MOD } \\
\text { (liter/150L) }\end{array}$} & \multicolumn{3}{|c|}{ Fertilization Dose(tons/ha/yr) } & \multirow{2}{*}{ Average } \\
\hline & 0 & 20 & 40 & \\
\hline \multicolumn{5}{|l|}{ Plant Height } \\
\hline 1 & 132,57 & 144,41 & 155,10 & $144,03^{b}$ \\
\hline 2 & 133,53 & 155,18 & 165,34 & $151,35^{\mathrm{a}}$ \\
\hline Average & $133,05^{\mathrm{C}}$ & $149,79^{\mathrm{b}}$ & $160,22^{\mathrm{a}}$ & \\
\hline \multicolumn{5}{|c|}{ Stem Diameter } \\
\hline 1 & 12,11 & 13,20 & 15,17 & $13,49^{b}$ \\
\hline 2 & 12,18 & 14,24 & 16,07 & $14,16^{\mathrm{a}}$ \\
\hline Average & $12,15^{\mathrm{c}}$ & $12,72^{\mathrm{b}}$ & $15,62^{\mathrm{a}}$ & \\
\hline \multicolumn{5}{|c|}{ Fresh Weight Production } \\
\hline 1 & 181,71 & 201,14 & 231,72 & $204,86^{\mathrm{b}}$ \\
\hline 2 & 182,01 & 219,44 & 245,95 & $215,80^{\mathrm{a}}$ \\
\hline Average & $181,86^{\mathrm{c}}$ & $210,29^{\mathrm{b}}$ & $238,23^{\mathrm{a}}$ & \\
\hline \multicolumn{5}{|c|}{ Dry Material Production } \\
\hline 1 & 45,22 & 49,04 & 53,39 & $49,21^{\mathrm{b}}$ \\
\hline 2 & 45,56 & 51,22 & 54,43 & $50,40^{\mathrm{a}}$ \\
\hline Average & $45,39^{\mathrm{c}}$ & $50,13^{\mathrm{b}}$ & $53,91^{\mathrm{a}}$ & \\
\hline
\end{tabular}

\subsection{Chemical Composition of Slurry}

Laboratory tests showed that in slurries with buffalo and water hyacinth input at a 1 liter / 150 liter MOD dose had a C / N ratio of 20.10 and at MOD 2 liter / 150 liter having C / N 15.48 means the slurry was mature and already meet the standards of Permentan and SNI. This is in accordance with the statement of Novizan [4] which states that good organic fertilizer is the one that mengandug $\mathrm{C} / \mathrm{N}$ ratio of $12-15$. The $\mathrm{C} /$ $\mathrm{N}$ ratio will affect nutrient availability, if $\mathrm{C} / \mathrm{N}$ ratio is inversely related to nutrient availability, meaning that if $\mathrm{C} / \mathrm{N}$ ratio is high then nutrient content is slightly available for crops, whereas if $\mathrm{C} / \mathrm{N}$ is low then the availability of nutrient and plants can meet the needs of his life.

\subsection{Plant height}

The result of variance showed that slurry with buffalo faeces and water hyacinth input with MOD gave significant effect $(\mathrm{P}<0,05)$ to indigofera zollingeriana plant height. The high value of plants using slurry fertilizer with buffalo faeces and water hyacinth with 2 liters $\operatorname{MOD}\left(\mathrm{M}_{2}\right)$ of $151,35 \mathrm{~cm}$, there is a tendency of higher growth rate when compared with MOD 1 liter $\left(\mathrm{M}_{1}\right)$ of $144,03 \mathrm{~cm}$. This is because the nitrogen content in $\mathrm{M}_{2}$ is greater than $0.35 \%$ compared to the nitrogen content found in $\mathrm{M} 1$ that is $0.26 \%$. This is in line with Prasetyo's [5] statement stating that nitrogen $(\mathrm{N})$ is the main nutrient for plant growth that is generally indispensable for the formation and growth of vegetative parts of plants, such as leaves, stems and roots. $\mathrm{N}$ functions for plants include: increase plant growth, nourish leaf growth, increase protein levels in plant body, improve the quality of leaf-producing plants, increase microorganisms in the soil.

The highest value of plant height in each treatment of dosage of slurry fertilizer was found in the treatment of 40 tons / ha / $\mathrm{yr}\left(\mathrm{P}_{2}\right)$ dosage of $160.22 \mathrm{~cm}$ and the lowest plant height was found in the control treatment $\left(\mathrm{P}_{0}\right)$ of $133.05 \mathrm{~cm}$. The results showed that the application of slurry fertilizer with buffalo fungus and water hyacinth input can increase plant height. Plant growth is the result of interaction between the inside and outside. Factors in including genetic traits in the form of genes and hormones. While external factors include macro nutrients and micro nutrients contained in the soil. In addition, light intensity is also very instrumental in the growth of plants that primarily in the process of photosynthesis of plants. Sitompul and Guritno [6] suggest that plant height is the parameter used to measure environmental influences. This is based on the fact that plant height is the most easily visible growth measure. As an environmental impact measurement parameter, plant height is sensitive to environmental factors such as fertilization. 


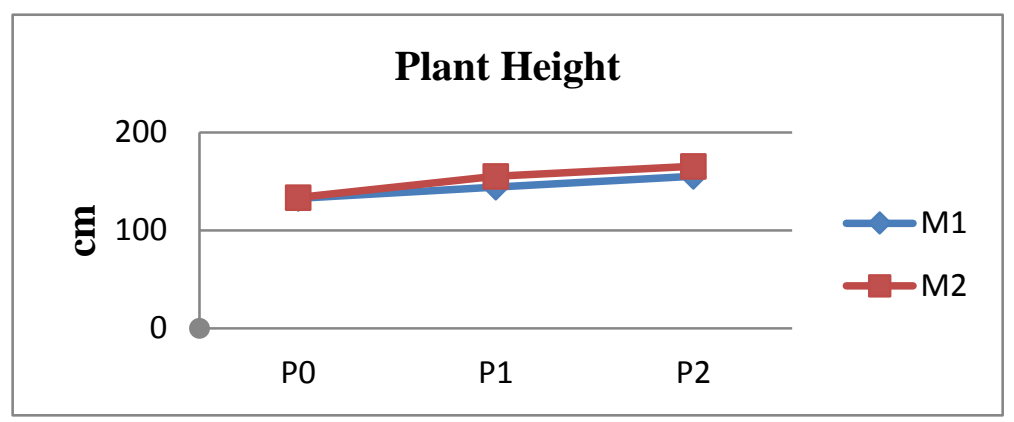

Figure 2. Height Indigofera zollingeriana plants with various doses of fertilization

Figure 2 shows that there is an interaction between Indigofera zollingeriana type differences and slurry with buffalo faeces and water hyacinth with various doses of MOD gives a significant effect on plant height. By following the curve of the higher the dose given the growth of plant height will also be higher. This is reinforced based on the duncan test to determine the differences between treatments. $\mathrm{P}_{2}$ on $\mathrm{M}_{2}$ showed a difference with the increase of plant height compared with other treatment, so that the utilization of slurry with buffalo faeces and water hyacinth in various doses of MOD had a very significant effect on plant height.

\subsection{Stem diameter}

The result of variance showed that slurry with buffalo faeces input and water hyacinth with MOD gave significant effect $(\mathrm{P}<0,05)$ to indigofera zollingeriana stem diameter. The highest value of stem diameter of indigofera zollingeriana which uses slurry fertilizer with buffalo faeces and water hyacinth with 2 liters MOD $\left(\mathrm{M}_{2}\right)$ of $14.16 \mathrm{~mm}$, there is a tendency to have better growth growth when compared with slurry input of buffalo feces with water hyacinth with 1 liter MOD $\left(\mathrm{M}_{1}\right)$ of $13.49 \mathrm{~mm}$. The residual slurry of biofuels of buffalo faeces and water hyacinth mixed with MOD has undergone anaerobic fermentation so as to have a better quality of organic fertilizer given directly without any treatment. With that then the slurry can increase the productivity of the plant. This is in accordance with the statement of Ayub [7] which states that the quality of the remaining slurry process of bio-gas making is better than the cattle dung directly from the cage. This is due to the process of fermentation in biodigester anaerobic reshuffle of organic matter into bio gas and organic acid having low molecular weight such as acetic acid, butyric acid and lactic acid. Increased organic acid will increase the concentration of elements of N, P and K. With these conditions, the slurry of bio gas has become a liquid organic fertilizer. The same thing is also stated by Suriadikarta et al., [8] which states that one of the organic fertilizers that can be used to increase the production of forage of fodder is slurry fertilizer.

The highest value of stem diameter per treatment of dosage of slurry fertilizer with buffalo and water hyacinth is found in treatment of 40 ton / ha / $\mathrm{yr}\left(\mathrm{P}_{2}\right)$ dose of $15.62 \mathrm{~mm}$ and the lowest diameter stem production is in control treatment $\left(\mathrm{P}_{0}\right) 12.15 \mathrm{~mm}$. The results showed that slurry with buffalo faeces and water hyacinths could increase the diameter of indigofera zollingeriana stem. This is related to the fulfillment of nutrients on the soil with slurry with the input of buffalo faeces and water hyacinth so that it changes the physical properties of the soil, especially the soil structure. It also increases the availability of water that is essential to the growth of vegetative plants. Increased values of vegetative character such as plant height and stem diameter are due to the role of the nitrogen element. The main role of nitrogen for plants is to stimulate overall growth, especially the stems, branches and leaves of Hardjowigeno [9]. Plants require nutrients that suit their needs in the process of growth and development.

The interaction between MOD dosage and dose of slurry fertilization with buffalo faeces and water hyacinth influences was not significant $(\mathrm{P}>0.05)$ to stem diameter. The unreal results indicate that the application of slurry fertilizer with buffalo faeces and water hyacinths have no effect on indigofera zollingeriana.

\subsection{Fresh Weight Production}

The result of variance showed that slurry with buffalo and water hyacinth input with MOD gave significant effect $(\mathrm{P}<0,05)$ to indigofera zollingeriana fresh weight production. The highest value of fresh weight production of indigofera zollingeriana using slurry fertilizer with buffalo faeces and water hyacinth input with 2 liters $\mathrm{MOD}\left(\mathrm{M}_{2}\right)$ of $215.80 \mathrm{~g}$ which has better growth when compared with slurry input of buffalo feces buffalo with water hyacinth with 1 liter $\operatorname{MOD}\left(\mathrm{M}_{1}\right)$ that is equal to $204,86 \mathrm{~g}$. This is due to the 
microbial content of slurry M2 more than the M1 fertilizer so it can accelerate the fermentation process. Fermentation may occur due to the presence of microorganisms present in suitable organic materials. This is in accordance with the statement Indriani [10] which states that MOD function in the process of fermentation and decomposition of organic materials. MOD is also useful in improving the physical, climatic, and biological properties of the soil, providing nutrients needed by plants, nourishing plants, increasing crop production, maintaining production stability.

The highest value of fresh weight production per treatment of dosage of slurry fertilizer with buffalo and water hyacinth is found at treatment of 40 ton / ha / year $\left(\mathrm{P}_{2}\right)$ of $238.83 \mathrm{~g}$ and the lowest fresh weight production is in the control treatment $\left(\mathrm{P}_{0}\right)$ of $181.86 \mathrm{~g}$. The results showed that slurry with buffalo faeces and water hyacinth could increase the production of fresh weight of indigofera zollingeriana. This is because the higher the number of doses of slurry fertilizer given to the plant, the higher the productivity of the plant. Samekto [11] states that fertilizers are plant nutrients that are generally naturally present in the soil, the atmosphere and in animal feces. Fertilizer plays an important role in improving crop yields, especially on land with low nutrient content. Organic fertilizers are able to muffle the surface layer of the soil, increase the population of microorganisms, enhance absorption and water storage so that soil fertility becomes increased.

The interaction between MOD dosage and dose of slurry fertilizer with buffalo faeces and water hyacinth influences gave a non-tangible effect $(\mathrm{P}>0.05)$ on fresh weight production. The unreal results indicate that the application of slurry fertilizer with buffalo faeces and water hyacinths have no effect on indigofera zollingeriana.

\subsection{Production of dry matter}

The result of variance showed that slurry with buffalo faeces and water hyacinth input with MOD gave significant effect $(\mathrm{P}<0,05)$ to indigofera zollingeriana dry matter production. The highest value of stem diameter of indigofera zollingeriana which uses slurry fertilizer with buffalo buffalo and water hyacinth with 2 liters MOD $\left(\mathrm{M}_{2}\right)$ of $50.40 \mathrm{~g}$, there is a tendency to have higher development when compared with slurry of bio-input of buffalo feces with water hyacinth with 1 liter MOD $\left(\mathrm{M}_{1}\right)$ of $49.21 \mathrm{~g}$. This is because with the application of slurry fertilizer with higher number of MOD doses can be more accelerating in improving soil structure and improve the metabolic conditions of microorganisms in the soil which is a source of food substances in plants. Lingga and Marsono [12] stated that organic fertilizer application can improve soil structure, increase soil absorption to water, improve living conditions in the soil, and as a source of food substances for plants. While the provision of urea fertilizer can stimulate overall growth especially branches, stems, leaves, and play an important role in the formation of green leaves.

The highest dry matter production value per treatment of dosage of slurry fertilizer with buffalo and water hyacinth is found in treatment of 40 ton / ha / $\mathrm{yr}\left(\mathrm{P}_{2}\right)$ dosage of $53.91 \mathrm{~g}$ and the lowest dry matter production is in the control treatment $\left(\mathrm{P}_{0}\right)$ of $45.39 \mathrm{~g}$. The results showed that slurry with buffalo faeces and water hyacinth could increase the production of dry matter of indigofera zollingeriana. This is due to the increasing number of slurry bio-gas fertilizers in the soil will activate microorganisms that play a role in improving soil structure that stimulates plant growth. Moenandir [13] who stated that the purpose of fertilization is to improve the growth and quality of results. Therefore, fertilizer is given when the plants need fertilizer in order to obtain maximum profit.

The interaction between MOD dosage and dose of slurry fertilization with buffalo faecal and water hyacinth input gave an unstable $(\mathrm{P}>0.05)$ effect on dry matter production. The unreal results indicate that the application of slurry fertilizer with buffalo faeces and water hyacinths have no effect on indigofera zollingeriana.

\section{Conclusions}

The higher use of slurry doses with buffalo faeces and water hyacinth (Eichornia crassipes) can increase the production of plant height, stem diameter, fresh weight and dry weight of indigofera zollingeriana. 2 liters / 150 liters of MOD dose resulted in higher plant yield, stem diameter, fresh weight and higher dry weight when compared to a 1 liter / 150 liter MOD dose. Giving a dose of 2 liters / 150 liters of MOD with a fertilization dose of 40 ton / ha / yr can increase the productivity of indigofera zollingeriana better. 


\section{References}

[1] Reksohadiprodjo, S., 1985. Produksi Biji Rumput dan legum Makanan Ternak Tropik. BPFE. Yogyakarta

[2] Ginting, N dan Mustamu. 2012. Pengaruh Pemakaian Berbagai Jenis Mulsa dan Dosis Sluri Terhadap Pertumbuhan dan Hasil Tanaman Spinach Varietas Alrite. Skripsi Fakultas Pertanian. Universitas Kristen Satya Wacana. Salatiga

[3] Lazcano, C., Brandon, M.G dan Domininguez, J. 2008. The Evaluation of Stability and Maturity During The Composting of Cattle Manuare, Chemosfer, Vol. Hal. 436-444

[4] Novizan, R. 2001. Pupuk Organik Tanaman. Penebar Swadaya, Jakarta.

[5] Prasetyo, A., 2014. Pengolahan Tanah Bagi Tanaman. Penebar Swadaya. Jakarta

[6] Sitompul D, dan Guritno, S. 1995. Lingkungan dan Tanaman. UGM Press. Yogyakarta.

[7] Ayub, S. P. 2004. Organik Cair. Aplikasi dan Manfaatnya. Agromedia. Jakarta.

[8] Suriadikarta, D. Ardi., R.D.M. Simanungkalit. 2006. Pupuk Organik dan Pupuk Hayati. Jawa Barat: Balai Besar Penelitian Dan Pengembangan Sumber Daya Lahan Pertanian. Hal 2. ISBN 978-9799474-57-5

[9] Hardjowigeno, S., 2007. Ilmu Tanah. PusakaUtama, Jakarta.

[10] Indriani, Y. H., 1999. Membuat Kompos Secara Kilat. Penebar Swadaya, Jakarta.

[11] Samekto, I. 2006. Pemupukan Tanaman. Kansius, Yogyakarta

[12] Lingga, P. Marsono.2008. Petunjuk Penggunaan Pupuk. Rajawali Press. Jakarta.

[13] Moenandir, J. 2004. Prinsip - prinsip Utama Cara Menyukseskan Produksi Pertanian. Bayumedia Publishing. Malang, Jawa Tengah 